\title{
English as a Medium of Instruction (EMI): A primary school teachers' and students' perceptions
}

\author{
Ernawati Ernawati ${ }^{1}$, Sofendi Sofendi ${ }^{*}$, Sary Silvhiany ${ }^{1}$ \\ ${ }^{1}$ Sriwijaya University, Indonesia \\ *Corresponding author, e-mail: sofendi@yahoo.com
}

\begin{abstract}
The English language is becoming a global lingua franca, given its association with critical turns such as globalization, global economy, international communication, and the Internet. Many countries try to develop their countries start from the educational sector and put English as the language needed to learn in schools of many countries such as Indonesia. The use of English was becoming a global phenomenon that English is becoming a language of instruction in schools. The impact of utilizing English suggests that in a few universal academic settings, there is an apace developing inclination for English received as a medium of instruction (EMI). EMI applied in many educational levels started from the University, High School, and even in the early grade, such as Primary School. With the use of EMI in many educational systems, several issues rose related to its use in the classroom. Many of the studies found a lack of English proficiency, both from teachers and students in the use of EMI and several other problems. Related to this issue, the researcher conducted a study. Through a qualitative study in a case study design, the perception of teachers and pupils of a primary school in Palembang was explored and investigated. The participants of this study were the fifth-grade teachers and pupils in Paramount School Palembang. The data were collected by open-ended interviews with 3 Science teachers, 2 Mathematics teachers and 12 pupils in Paramount School Palembang. Thematic analysis was used in analyzing the data, and then the data were coded and classified into categories to form big themes based on the perceptions and information. The data analyzed revealed a consistency between teachers' and pupils' perceptions about EMI use in the classroom. The result mentioned that the teachers and pupils had positive perceptions because of the benefit of using English as a medium of instruction.
\end{abstract}

Keywords: English as A Medium of Instruction (EMI), Perception, Teachers, Students, Primary School.

How to Cite: Ernawati. E, Sofendi. S, Silvhany. S. (2021). English as a Medium of Instruction (EMI): A primary school teachers' and students' perceptions. International Research in Counseling and Education, 5 (1): pp. 24-32, DOI: http://doi.org/10.24036/00414za0002

\section{Introduction}

Many countries in the world compete in many aspects such as social, political, economic, and also education activities across regions and continents in this globalization era. One thing that will not escape from developing those aspects is the language because language is a bridge for all developments. According to (Banga \& Suri, 2015), language is a fundamental way to interact with the people around us. Even more, language has become a powerful tool for communication between countries, cultural teams, communities, varied corporations and organizations, and friends. In this regard, countries in the world need a language that can facilitate them to communicate with each other in addition to competing or even build cooperation between countries, especially in the educational sector because the language in education is one of the essential pillars of a country's future and the building block of a brighter generation (Alloush et al., 2020)

In line with the importance of the language, Tang (2020) characterized English as a global language. Consequently, the teaching English as a foreign language (EFL) has become a universal demand. English is the key as a universal language that enable/s all nations to examine and arrange social, political, financial, and instruction issues. Due to its increasing role as a lingua franca, English is frequently usual to communicate among individuals all over the world Considering the role of English in economic, science and technology development, many countries consider adapting English as the language of instruction in their educational 
institutions. In order to compete in this globalization era and improve human resources quality, in the year 2005 the Indonesian government has previously developed and organized an educational program based on Undang-Undang No. 20 the Year 2003 named Rintisan Sekolah Bertaraf Internasional(RSBI), which was meant as a program of government for some schools that facilitate the students with an international learning process where the English language was used not only as a subject to learned but also as a medium of instruction in learning process. In this case, the government requires the use of English as an important thing to learn at schools as a subject also as a medium of instruction to improve the quality of students in facing the era of globalization. Over time, the educational program or Rintisan Sekolah Bertaraf Internasional(RSBI) shifted in 2013 to weigh the various pros and cons. However, over time, some of the schools in Indonesia especially the private schools that were joined RSBI program continue the international standard learning by implementing the English language and following the overseas curricula such as Cambridge, Pearson Edexcel ,and etc. With the existence of those schools that continue to apply the use of English in their school environment, the habit of using English as communication at school is used as a tool to create a vision to be achieved. The impact of using English means in many international educational contexts that there is a rapidly growing tendency for English to be adopted as a medium of instruction (EMI) in teaching when a majority of the population speaks a local language like Indonesia (Dearden, 2015)

EMI a phenomenon that is growing rapidly in school in the era of globalization (Dearden, 2015). She also defined EMI as "the use of the English language to teach academic subjects in countries or jurisdictions where the first language (L1) of most of the population is not English". Using EMI is very relevant in countries with a colonial past where educational systems were established by the British (Mahboob, 2020). EMI means English is not only used as the content of the subject, but it is also the language of instruction on some subjects in schools. This seemingly inexorable trend of EMI adoption is in response to an ideology that teaching core subjects through English will enhance learners' English proficiency and hence the possibilities for better socioeconomic mobility (Haidar, 2017). Similar to Hamid et al. (2013), drawing on the studies in the volume, summarized that the primary goals of EMI in Asia are to enhance English language proficiency, develop human capital to enter the global economy, improve the quality of education, and internationalize local business and education. In practice, some private schools have more preference for using EMI than public schools (Mahboob, 2020; Rahman, 2020). Therefore parents who think to have a better future for their kids prefer to get their kids having the education in private school who apply EMI (Nuncio et al., 2020).

Most of the study of EMI focus on the higher level of education like study done by Walkinshaw et al. (2017), this study focus on the implementation of EMI in Asia-Pacific Higher education and a study done about challenges in using EMI that investigated a new EMI undergraduate program in Vietnam by (Vu \& Burns, 2014). Those studies focus on the higher education because as the upper education in this globalization era, the aim of EMI is to prepare an international career for the students (Çağatay, 2018). The use of EMI is synonymous with the upper education such as senior high schools and universities because of the need for international language on doing the study and the need of English skills for locating info within the Internet; reading actual info from skilled fields in books, scientific papers; communication with foreign colleagues in conferences, forums, Etc., that principally use English in apply. At this point, Panggabean (2016) mentioned that English language skills, especially in writing scientific papers, cannot be achieved in a short time but in a long time through the process of using English and practice through trial and error. It means that English's ability should be start from the early grades. It means that the use of EMI could be started at primary school level as the early starter. The use of EMI was found in many primary schools in many countries such as Indonesia. Along the use of EMI in learning in primary school, some challenges faced by the teachers in using EMI. The literature identifies four major EMI challenges facing teachers, including teachers' language abilities, students' proficiency, appropriate methods, and inadequate resources (Vu \& Burns, 2014). This issue is important to be studied since it has been a dilemma for students and teachers on using EMI. It also mentioned that the English language used as a medium of instruction in early grades has some understudied issues (Alaa Q. Alhourani, 2021; Mahboob, 2020). Moreover, the study about EMI in primary schools is still limited in Indonesia. Since the lower level of education (primary school) also adopts EMI, the writers believes that EMI implementation in primary school should be studied because there will be some issues inside the implementation of EMI in primary schools . Finding the perceptions of the stakeholders were so important to see the implementation of EMI. So, this study focused on the teachers' and students' perceptions about using EMI. Researching teachers' and students' perceptions are essential because their views may negate those of other key stakeholders (Pun \& Thomas, 2020). Therefore, the concerns about them should be taken seriously. To fill the gap, the authors would like to debate a number of the perception featured of the use of EMI by the early grade of education. By studying the perception of the teachers and students in EMI in a private primary school, the writers believe it could contribute information about the use of EMI in early grade so that the use of EMI will be used much well in the days ahead. 


\section{Method}

The study was intended to point out what are the perceptions of the teachers and students about using English as a medium of instruction in the teaching and learning process. In this study, the writers used a qualitative case study. A qualitative study was characterized as an research process of understanding a social or human issue, based on building a complex, holistic picture, formed with words, reporting detailed views of informants, and conducting a setting characteristic (John W \& Creswell, 2018). The writerss chose qualitative as the research method because qualitative research focuses on understanding social events from the perspective of the human participant.

The study was conducted in the Second Semester of the 2020/2021 Academic Year. The location of the study was at the fifth grade of Paramount School Palembang, Indonesia. The study was taken in this school because it is one of the private primary schools that used EMI in their learning. The reason for choosing the fifth grade is because this school recognizes EMI is more actively used at that level and because of students' experience in using it longer than other classes.

The participants of this research are five (5) teachers that consist of 3 (three) science teachers and two (2) mathematics teachers who are taught at the fifth grade of the 2020-2021 Academic Year. Besides, the writers also invite twelve (12) students of the fifth grade of the 2020-2021 Academic Year. The participants were selected with convenience sampling. The convenience sampling is better for the accessibility and availability of the participants in conducting the study to get the maximum results (Etikan et al., 2016). Then, they had gained experience in using EMI in their teaching and learning process. Besides, they shared their perception related to the research question.

In this study, the researchers used a semi-structured interview with open-ended questions for teachers and students. The interviews used Indonesian to make the interviewees easy to answer and share their thought. The interview conducted in online meeting by using zoom application. The purposes of the interviews were to know the perceptions of teachers and students about using EMI. The interviewer can expand and investigate the interviewees' responses more deeply through a flexible interview named semi-structured interview (Alshenqeeti, 2014).

Data collection also relied on visual method with drawing techniques to get more in depth understanding of the students' voices regarding their experience (Elden, 2012) and opinion of the EMI implementation in their school. Furthermore, visual method can complement the interview process in the situation in which children found it challenges to express their opinion or describe their experiences verbally. In her research with bilingual children, Silvhiany (2019) found that drawing allowed children to express subtle nuances of their identity construction and lingua cultural experiences.

The drawing techniques in this research comprised of free drawing and language portrait (Busch, 2018). Drawings provide a special quite glimpse into human sense-making than written or spoken texts do, because they can reveal that which is not easily put into words: the ineffable, the elusive, the not-yet-thought-through, the subconscious (Weber and Mitchell, 1995, as cited in Kearney \& Hyle, 2004). In this drawing interview procedure, the researchers asked a question related to the students' feeling about using EMI for science and mathematics lesson. The researchers asked the students to draw their feelings into a drawing; the students can draw anything they wanted as it could show their feelings. The students can use manual drawing/written or some technology for drawing. Due to the Covid19 Pandemic, the interview meeting couldn't be held directly, the technology tools chose for their drawing to make easy the interviewer checked it. Some of them used written drawing and share it in the video and a capture, some used Paint application in laptop they used and some are use application called "Ibis Paint" in their tablet or hand phone. The interview can see the interviewees draw with the sharing screen on the Zoom application and taking the screen shoot of their drawings. The interviewer will ask some of the point of their drawing and the students will explain their drawing orally.

The data analysis was taken from interviews and drawing feelings. After collecting the data using the interview and drawing, the researchers read all the answers and explanations, classified the topic into a similar category. All the interview results were then transcribed, and the data were analyzed by thematic analysis. The thematic analysis focused on reading and coding the data (Braun \& Clarke, 2006). Finally, conclusions were drawn from the findings.

\section{Results and Discussion}

This section presented the result of the interviews data. Based on the data results, there were various perceptions from teachers and students. Teachers' and students' perceptions drawn into some themes are teachers' and students' reactions or opinions and benefits about using EMI. 
At the first section the researchers will describe teachers' and students' reactions or opinions about using EMI in teaching and learning science and Mathematics in the classroom. Based on their reactions or opinions in the interview, there are four (4) categories of opinions that the researchers already selected into similar reactions. Table 1 displayed the data, which had analyzed into several categories.

\begin{tabular}{|c|c|c|c|c|}
\hline Reactions or Opinions & $\begin{array}{c}\text { Number of } \\
\text { Teachers }\end{array}$ & Percentage & $\begin{array}{c}\text { Number of } \\
\text { Students }\end{array}$ & Percentage \\
\hline $\begin{array}{l}\text { Positive Reactions or } \\
\text { Opinions }\end{array}$ & 5 & $100 \%$ & 5 & $41,67 \%$ \\
\hline $\begin{array}{l}\text { Negative Reactions or } \\
\text { Opinions }\end{array}$ & - & - & 1 & $8.33 \%$ \\
\hline $\begin{array}{l}\text { Positive and Negative } \\
\text { Reactions or Opinions }\end{array}$ & - & - & 5 & $41,67 \%$ \\
\hline $\begin{array}{l}\text { Neutral Reactions or } \\
\text { Opinions }\end{array}$ & - & - & 1 & $8,33 \%$ \\
\hline Total & 5 Teachers & $100 \%$ & 12 Students & $100 \%$ \\
\hline
\end{tabular}

The first response or opinions that will be showed is the positive reactions or opinions about using EMI in science and mathematics lesson both from teachers and students. As the first discussion in these positive reactions, the writers will show the perception from the teachers' side. From all five (5) teachers that have already interviewed, all mentioned that the use of EMI has a very big beneficial for both of them as teachers and for their students.

Generally, five (100\%) of teachers interviewed said that the use of EMI in their teaching is very good and beneficial. The teachers are really knew the needs of English that is why they are all having positive perception toward EMI. The benefits they mentioned are varies. Based on 3 of them, English is playing a big role in this Globalization Era where English is an International language. They said, nowadays all the facilities in private or in public areas are all using English. Besides, they also confirmed that because of their teaching are using EMI, it trained them and make them become confident to use EMI. Here are two of their statements:

Excerpt 1:

Yes, in my own opinion is excellent, because, in this era of globalization, English has become a necessity for everyone to use English. Likewise, in education, English is used as the language of instruction to get used to it, get used to hearing, and speak using English.

(Teacher 1's interview answer, March 2021, translated by the researchers)

\section{Excerpt 2:}

Yes, in my opinion, it is good, miss. If we use English in the language of instruction or instruction to our students, especially in lessons where the book is in English, we know today what is called global, yes, language England once worldwide. Everywhere the language is the most superior, yes, wherever we go, we must use English to meet tourists or children. Maybe a vacation outside is essential, and indeed for those who are still in the primary school category, they have to introduce the English early to them. Moreover, it would be better if it was related to the lesson so.

(Teacher 2's interview answer, March 2021, translated by the researchers)

Then, based on the pupil's side, five $(41,67 \%)$ students showed positive reactions toward using EMI without any negative reactions. The students said the use of EMI has so many benefits for them as students. These students mentioned that of the use of EMI, they could get knowledge about two things like Math-English or Science-English at once. Besides the focus on learning the subject like science and mathematics, they also learn English when the teacher used EMI in those lessons. Then, they mentioned that using EMI helped them to get more knowledge in her learning. Not only that, the use of EMI has a positive impact on their communication skills in English and for their future if they have the opportunity to continue their studies abroad.

Excerpt 3:

It's pretty cool. You can get more knowledge about mathematics and English at the same time. (Pupil 2's interview answer, March 2021, translated by the researchers) 


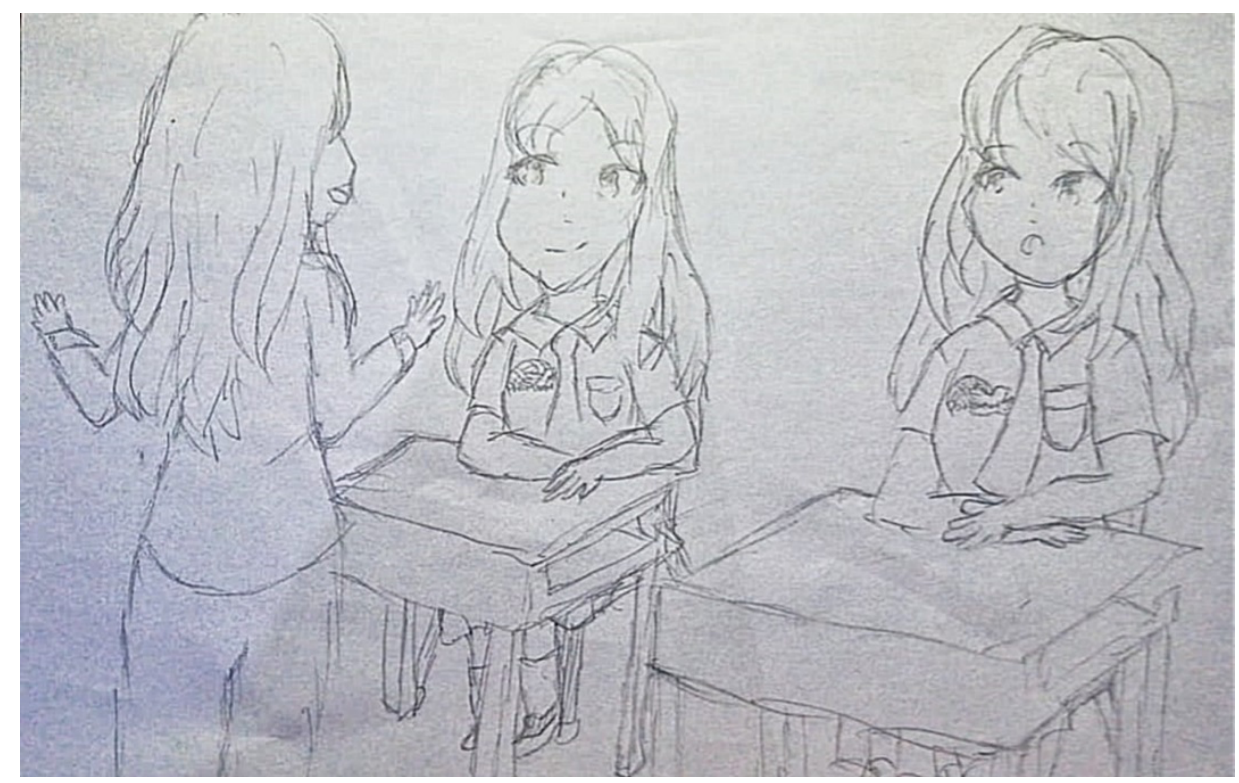

Figure 1: One of the girls in the left one is me, then the girl opposite her is R, and of course, the teacher that teaches some English. I understood immediately because I used English as my language. (Interviewer: you meant you used English daily, so that easy for you to understand?) Yes. (Interviewer: do you have any issue related to the materials that teach with EMI?) No, I already learn some stuff earlier than I was supposed to know it. It made me understand well when I will learn it at school.

This figure 1 was a drawing by pupil 2 with written drawing. As in her interview section, she mentioned that using EMI has benefits where she can get knowledge about English out of in English lesson. The researchers added some of the information from her drawing interview. Her drawing interview helped er drawing interview helps to explain more about her perception of EMI. With a background that has a habit of using English daily at home. This pupil has a good perception of the usefulness of English. The need for English is evident in her, as evidenced by her parents, who create an atmosphere by using English at home. This explained that parents know very well the need for English for their kids. That way, there is no difficulty in using English as the language of instruction for these students. Another positive statement also came from other students. They mentioned:

\section{Excerpt 4:}

It's beneficial to practice our English ability and adding knowledge about English.

(Pupil 10's interview answer, March 2021, translated by the researchers)

\section{Excerpt 5:}

Because it will be beneficial, we will get better trained in our English than in English and later when we grow up and want to go abroad. We need to use English if we can't speak English. It will be hard.

(Pupil 9's interview answer, March 2021, translated by the researchers)

From the excerpts and figure above, the participants could improve their English ability through EMI in their learning. The findings above, similar to a study of EMI done by Bahiyyah (2019) positive reactions were dominated the participants' perceptions in her research. The participants have motives to be mastered English and need the English language as an international language.

The second reactions or opinions were negative reactions or opinions about EMI use in the learning process. Only one pupil (8,33\%) from $12(100 \%)$ students shared her negative reactions to EMI. It means that a pupil disagrees about the use of EMI in the learning process. This participant explained that the use of English in her learning is problematic even though the teacher sometimes mixed the language with Indonesian. She mentioned that the use of English is hard because she has an issue with pronunciations.

Excerpt 6:

I think, what to do, it's a bit difficult. The pronunciation is that kind of troublesome to be understood.

(Pupil 12's interview answer, March 2021, translated by the researchers) 
According to the excerpt, there a fear felt by one pupil because of a lack of pronunciation. The pronunciation was the biggest problem that this pupil faced when the teachers needed to teach her with EMI, and she needed to respond to it with English. Similar to Macaro (2018), lack of attention to language needs, ineffective teaching practices, and poor student interactions commonly reported. Most of the students who have negative perceptions are students who lack knowledge about the needs of English.

The third reactions or opinions were positive and negative (double) reactions or opinions. Some students have a double reaction toward the use of EMI. Some of these students think that the use of EMI has positive and negative side in learning. The students with the double reactions. There were five $(41,67 \%)$ students who chose double reactions. Besides knowing EMI was beneficial as their positive perception, they also had negative opinions since they felt difficulties using it. However, because they have motives and know the English need, they realize that EMI was suitable to be used. Here is one of the statements:

\section{Excerpt 7:}

When we learned an English subject, we haven't learned some of the vocabularies in it. So there (in science and mathematics subject) we will know what it meant. It is also beneficial. I like it, but maybe they're something I don't like. Usually, there is something I don't understand. That's what I don't like. (Pupil 7's interview answer, March 2021, translated by the researchers)

To see the perception more about using EMI, the researchers added the drawing feeling interview based on pupil 7's drawing interview section.

Figures 2:



Figure 2: So the meaning of this picture is a combination of mathematics and science. So there I have two feelings. I showed happily, and one other is dizzy. (Interviewer: the happy one is in the "yeay"?) yes, the "yeay" one, then feeling for the sad one is the "tangled" one. (Interviewer: why do you feel happy?) sometimes, I feel happy because I learned a lot about new words in English, then I can learn well. Usually, I will feel dizzy if I do not understand the language. (Interviewer: so sometimes you feel happy and sometimes you feel sad) yeah, I feel sad just because if I could not understand. So if I don't understand and forget something about the lesson, I will not be in the mood. (Interviewer: How you feel not in the mood?) I feel like I want to mad at myself, but I know that is my fault.

This drawing section held online with zoom meeting and the pupil used "Ibis Paint" in her tablet. Seeing from the interview sections and figure 2 with some of the students, their positive opinions or reactions were similar to each other where they think that the use of EMI may enrich their English vocabularies about science and mathematics. They also think that using EMI makes them practice their English skill not only when they are learning English subjects but also when they are learning science and mathematics. Similarly, in her study, 
Ratna (2017) uses EMI to enrich vocabulary and speaking skills, practice speaking English, and become accustomed to speaking English. Building students' self-confidence to talk in English makes students understand what people say in English before the EMI was implemented. The negative reactions side appeared because of their problems in teacher's words used when the teachers explained the lesson. The students also claimed the difficulties in came because of their lower vocabulary.

The last reaction is about students' perception of EMI that has a neutral reaction. There was only one pupil that had a neutral reaction. The pupil doesn't mention positive or negative reaction to EMI. He said that at this time, it was only a common thing when there was learning by using English. There was no specific reaction when he asked about the use of EMI. He also added it is just so so. He claimed that when the teacher explained him in English, he understood and has no problems.

Excerpt 8:

For me, yes, if there is a math Pearson is English, that's a common thing. If I say I understand, yes, I will. In my opinion, it's not bad. Just so so.

(Pupil 5's interview answer, March 2021, translated by the researchers)

According to the excerpt above, the pupil with the neutral perception looks like he is used to using English, so that it is a matter of course and perfectly normal for him. Neither good nor bad. This pupil has no specific purpose or needs to use English.

\section{Conclusion}

Based on the results, it can be concluded from the research data that all of the teachers who teach in grade five for science and mathematics subjects have a positive perception in the use of EMI. This was indicated by their positive reactions and opinions that they mentioned in the interview. Their opinion about the use of EMI at this primary school can improve students' English skills and prepare students for the international competitions, besides those teachers also felt some benefits because it could increase their confidence in speaking English. On the other hand, almost all students who were interviewed and described their feelings about EMI had positive perceptions. This can be seen in their positive reactions and opinions on the usefulness of EMI. EMI can improve their English language skills, enrich their vocabularies, prepare them to have better study in the future and make them easy to understand the English language although some of them still have problems in using it due to their low vocabulary and pronunciation skills of English. Thus, the researchers concluded that both of the teachers and students in this grade 5 in a primary school in Palembang knew very well about the need for English as an important language. On the other hand, with little voice about their negative opinion about EMI, the researchers concluded that there were still students who need to be motivated and learn more about the need for English in this era of globalization. Therefore, to optimize this research, the researchers suggest that further research be conducted to investigate more about the issue of the students' need about English as a medium of instruction in this globalization era.

\section{References}

Alaa Q. Alhourani. (2021). Investigating the match and mismatch between students' learning styles and teacher's teaching styles in a Saudi school: A case study. Journal of World Englishes and Educational Practices (JWEEP), 2, 10-20. https://doi.org/10.32996/jweep

Alloush, I., Chaleila, W., \& Watted, A. (2020). Close to the heart or close to the home? Motivational factors influencing EFL teaching as a career choice among female Arab-Israeli students. English Language Teaching, 14(1), 48. https://doi.org/10.5539/elt.v14n1p48

Alshenqeeti, H. (2014). Interviewing as a data collection method: A critical review. English Linguistics Research, 3(1), 39-45. https://doi.org/10.5430/elr.v3n1p39

Bahiyyah, K. (2019). The Students' perception of using English as medium of instructiob (EMI) in English lesson for the 10th grade students of SMAN2 Salatiga in the academic year 2018-2019. State Institute for Islamic Studies Salatida.

Banga, C. L., \& Suri, J. (2015). Role of Language In Human Life. International Journal of English Language, Literature and Humanities, 3(7), 180-197. https://ijellh.com/wp-content/uploads/2015/09/16.-ChamanLal-Banga-paper-final.pdf?_cf_chl_jschl_tk_=767bf22e587644d537b484b2fd9fd3156e2ff6ff1576347779-0AdTAbIeELBM_MBT9G9EEkgiF_abTS4sQCqijd80dpZU4WMNVMLIjxxumKOuXZoEmRYNLQN8kMK9MVb alahnmQit6DE6-NV1ZS3 
Braun, V., \& Clarke, V. (2006). Using thematic analysis in psychology. Qualitative Research in Psychology, 3(2), 77-101. https://doi.org/10.1191/1478088706qp063oa

Busch, B. (2018). The language portrait in multilingualism research: Theoretical and methodological considerations.

Çaatay, S. (2018). The pros and cons of English-medium instruction in higher education in an EFL context. In Journal of Foreign Language Education and Technology (Vol. 4, Issue 2). http://jflet.com/jflet/206http://jflet.com/jflet/

Dearden, J. (2015). English medium instruction: A growing global phenomenon. London, UK: British Council. https://doi.org/10.13140/RG.2.2.12079.94888

Elden, S. (2012). Inviting the messy: Drawing methods and 'children's voices.' Childhood, 1(20), 66-81. https://doi.org/10.1177/0907568212447243

Etikan, I., Musa, S. A., \& Alkassim, R. S. (2016). Comparison of convenience sampling and purposive sampling. American Journal of Theoretical and Applied Statistics, 5(1), 1. https://doi.org/10.11648/j.ajtas.20160501.11

Haidar, S. (2017). Access to English in Pakistan: inculcating prestige and leadership through instruction in elite schools. International Journal of Bilingual Education and Bilingualism. https://doi.org/https://doi.org/10.1080/13670050.2017.1320352

Hamid, M. O., Nguyen, H. T. M., \& Jr. Richard B. Baldauf. (2013). Medium of instruction in Asia: Context, processes and outcomes. Current Issues in Language Planning, 1(14), 1-15. https://doi.org/10.1080/14664208.2013.792130

John W, C., \& Creswell, J. D. (2018). Research design: Qualitative, quantitative, and mixed methods approaches (5th ed.). Sage.

Kearney, K. S., \& Hyle, A. E. (2004). Drawing out emotions: The use of participant-produced drawings in qualitative inquiry. Qualitative Research, 4(3), 361-382. https://doi.org/10.1177/1468794104047234

Macaro, E. (2018). English medium instruction (Oxford App). Oxford: Oxford University Press.

Mahboob, A. (2020). Has English medium instruction failed in Pakistan? In J. F. D. Giri, R., Sharma, A. and D'Angelo (Ed.), Functional Variation in English: Theoretical considerations and practical challenges (pp. 261-276). Springer. https://doi.org/10.1007/978-3-030-52225-4_17

Nuncio, R. V., Arcinas, M. M., Lucas, R. I. G., Alontaga, J. V. Q., Neri, S. G. T., \& Carpena, J. M. (2020). An Elearning outreach program for public schools: Findings and lessons learned based on a pilot program in Makati City and Cabuyao City, Laguna, Philippines. Evaluation and Program Planning, 82, 101846. https://doi.org/10.1016/j.evalprogplan.2020.101846

Panggabean, H. (2016). Urgensi kompetensi linguistik dalam masyarakat ekonomi ASEAN(MEA). https://www.researchgate.net/publication/313160996_URGENSI_DAN_POSISI_BAHASA_INGGRIS_DI_IN DONESIA

Pun, J. K. H., \& Thomas, N. (2020). English medium instruction: Teachers' challenges and coping strategies. ELT Journal, 74(3), 247-257. https://doi.org/10.1093/elt/ccaa024

Rahman, T. (2020). English in Pakistan: Past, present and future. In J. Giri, Ram Ashish, Sharma, Anamika, D'Angelo (Ed.), Functional Variation in English: Theoretical considerations and practical challenges (pp. 127-148). Springer. https://doi.org/10.1007/978-3-030-52225-4_9

Ratna, A. (2017). Controversy behind applying EMI (English as the Medium of Instruction) among EFL students. 82(Conaplin 9), 58-63. https://doi.org/10.2991/conaplin-16.2017.12

Silvhiany, S. (2019). Indonesian education migrant families' language, literacy, and identity navigations in transnational spaces. (Order No. 13900644) [Doctoral dissertation, Indiana University]. ProQuest Dissertations and Theses Global.

Tang, K. N. (2020). Challenges and importance of taching English as a medium of instruction in Thailand international college. The Journal of English as an International Language, 15(2), 97-118. file:///C:/Users/user/Downloads/76383000 (1).pdf 
Vu, N., \& Burns, A. (2014). English as a medium of instruction: Challenges for Vietnamese tertiary lecturers. Journal of Asia TEFL, 11(3), 1-31. https://doi.org/10.4324/9780367854850-10

Walkinshaw, I., Fenton-Smith, B., \& Humphreys, P. (2017). EMI issues and challenges in Asia-Pacific higher education: An introduction. 1-18. https://doi.org/10.1007/978-3-319-51976-0_1 